\title{
MODELLING OF BEETROOT SEEDLINGS WITH MODIFIED GENERALIZED LOGISTIC FUNCTIONS
}

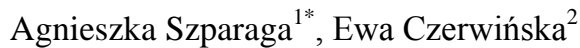 \\ ${ }^{1}$ Department of Agrobiotechnology, Koszalin University of Technology \\ ${ }^{2}$ Department of Biomedical Engineering, Koszalin University of Technology \\ "Corresponding author: e-mail: agnieszka.szparaga@tu.koszalin.pl
}

\begin{tabular}{|c|c|}
\hline ARTICLE INFO & ABSTRACT \\
\hline $\begin{array}{l}\text { Article history: } \\
\text { Received: March } 2017 \\
\text { Received in the revised form: } \\
\text { June } 2017 \\
\text { Accepted: June } 2017 \\
\end{array}$ & $\begin{array}{l}\text { Modified generalized logistic functions (also known as Koya-Goshu } \\
\text { functions) were used for mathematical description of germination. } \\
\text { These functions constitute natural modification of traditionally used } \\
\text { Richards' function for description of plants germination that introduc- } \\
\text { es a non-linear time increase in exponent and an element related to }\end{array}$ \\
\hline $\begin{array}{l}\text { Key words: } \\
\text { beetroot, } \\
\text { seedlings, } \\
\text { water extracts, } \\
\text { logistic functions, } \\
\text { Koya-Goshu functions }\end{array}$ & $\begin{array}{l}\text { time shift. Curves were adjusted to experimental data based on mini- } \\
\text { mization of the square sum of difference between experimental data } \\
\text { and a mathematical model (the smallest squares method). Results of } \\
\text { simulation research show that the determined parameters of curves } \\
\text { (e.g., values of the growth parameter, time shift or upper limit of } \\
\text { population) describing the number of seedlings as a time function stay } \\
\text { compliant to interpretation with regard to biology of the investigated } \\
\text { processes. Based on the research, it was stated that for control and } \\
\text { application of plant extracts to soil, Koyu-Gosha model has better } \\
\text { adjustment to experimental data in comparison to the generalized } \\
\text { logistic model. }\end{array}$ \\
\hline
\end{tabular}

\section{Introduction}

The value of sowable material considerably depends on substances that are used in plant protection for seed dressing. The main objective of the integrated protection system is application of alternative, biological substances instead of chemical ones. It is beneficial both for the plants form and their yield as well as for biodiversity of soil environment (Brachaczek et al., 2012).

Modern methods used by molecular biology or biotechnology may modify plant properties in a direction which favours their strength, but searching for plant species with a positive impact on seed yield is cheaper and safer for protection of environment (allelopatia). Extracts from various plant species are used in folk medicine, herb healing and cosmetics industry. However, only in recent years they have become being recognized as a possible source of antimicrobial compounds, which may be used in plant protection (Czerwińska and Szparaga, 2015a, 2015b; Czerwińska et al., 2015; Czerwińska 2015; Adaszyńska et al., 2013; Boskovic et al., 2013; Bozin et al., 2006). The use of water extracts in plant protection in integrated agriculture may limit the use of synthetic substances and in organic agri- 
culture may strengthen environment resistance thanks to protection of its biodiversity (Mrówczyński et al., 2009). Because of pathogens in seeds and soil, pre-sowing seed pickling has become a necessity, since non-pickled seeds weakly germinate and infected seedlings underdevelop or die. It results in reduction of the number of plants during the vegetation period, low stocking density of plants during harvesting and low yield of poorer quality. It should be also emphasised that the use of chemical substances, extensively applied in traditional agriculture, is prohibited in traditional agriculture. Thereby, alternative, non-chemical methods of pre-sow seed dressing based on natural antifungal, antibacterial or antivirus substances present in herbs or essential oils are searched for (Rochalska et al., 2010; Orzeszko-Rywka and Rochalska, 2007; Rochalska and Orzeszko-Rywka, 2009).

Seed germination ability and plant germination in climatic conditions of Poland very often do not achieve a level defined by applicable quality standards. Ability to predict time when seedlings appear based on mathematical methods is considered as an element of the integrated crop production management system (Muszyński et al., 2015) Many works indicate the need of cooperation of specialists in many fields. Possibility of improvement and prediction of germination is crucial in agriculture since it is related to introduction and optimization of the newest technologies, both of precise agriculture and plant production (Hageseth and Joyner, 1975; Hsu et al., 1984; Muszyński et al., 2015; Odabas and Mut, 2007; O’Neill et al., 2004; Shafii et al., 1991; Shafii et al., 2001). Thus, for construction and use of plant germination predicting models, it is necessary to understand that the model is not only a method for determination of how the environment models the germination speed within the time slot but also a tool for determination of time when environment will influence this time slot.

Based on the analysis of many scientific works, one may observe two approaches in modelling of both germination of seeds and seedlings. The first one is the use of empirical models, the second one is a model of mechanisms which governs biological processes. Empirical models may be useful in adjusting specific results of seed germination ability. However, modern modelling of these biological processes requires and will require definition and measurements of new empirical variables (Brown and Mayer, 1988). The fact that empirical approach for modelling is justified in many experimental research cannot be undermined. However, researchers often have difficulties with interpretation of the biological meaning based on the obtained parameters of a model (Bradford, 1990). Predictability and distribution of germination models depend on the species and individual properties of plants. Therefore, research on modelling of these phenomena should be still carried out and extended, including particularly field conditions. Mathematical description of biological growth (the so-called population models) is significant in many fields of science in particular in: biology, agriculture and forestry (Burkhart and Tome, 2012). In the recent 200 years many researchers have developed the so-called growth models. The most important include the equations by: Verhulst, Von Bertalanffy, Gompertz, Richards, Blumberg, Mitscherlich, Weibull and the so-called generalized logistic equation (Koya and Goshu, 2013; France and Thornley, 1984; Tsoularis and Wallace, 2002). Clear analytical solutions of the generalized logistic equation, the co-called generalized logistic functions, should be emphasised among the listed models. Eberhardt and Breiwick (2012) applied them for modelling of the growth of birds and mammals population and Carlson (1913) thanks to them described the growth of yeast for the first time (Carlson, 1913). Morgan (1976) used the logistic equation for description of behaviour of African elephants (Morgan, 1976). While Kerbs (1985) used the 
Modelling of beetroot seedlings...

logistic equation of Verhulst for mathematical description of population data for Peruvian anchois (Krebs, 1985; Tsoularis and Wallace, 2002). The recent successes of application of generalized logistic functions cause that they are still in the centre of interest of many researchers. In particular, Koya and Goshu (2013) who suggested the original modification of generalized logistic functions, which includes popular growth functions, such as: Verhulst, Gompertz, Brody, Mitscherlich, von Bertalanffy, Richards and generalized by Weibull (Koya and Goshu, 2013). So far, the suggested functions have not been used for description of a specific problem with a biological context, which makes them possibly interesting with this regard.

The paper presents the use of the generalized logistic function and Koya-Goshu functions for mathematical description of beetroot germination (Beta vulgaris $L$. var. Conditiva Alef.) 'Czerwona Kula' variety, for which two methods of application of Artemisia absinthium (wormwood) herb infusion were used.

\section{Materials and methods}

The presented paper uses the results of the previously carried out and published research. Plants, which were used to produce extracts, were selected based on the previous in vitro experiment that aimed at evaluation of germination ability and healthiness of a beetroot, whose seeds were treated with extracts in the form of infusions, macerates and decoction of various morphological parts of 40 plant species (Czerwińska et al., 2015 b). Research was carried out pursuant to the provisions of the International Seed Testing Association - Chapter 7 (ISTA 2013). Extracts from from Artemisia absinthium (herb), which in in vitro tests stimulated healthiness and liveliness of the analysed sowing material, was used for treating seeds and in-soil application. Plant germination was analysed in pot experiment carried out in plastic containers for seedlings that comprised 40 pots with a diameter of $50 \mathrm{~mm}$ and depth of $50 \mathrm{~mm}$. 40 seeds of the selected plants cultivated individually to each pot were sowed to each container filled with podzol soil on a weak clay sand and gravel ground of 4th soil class of good rye complex, on the depth of $1.5 \mathrm{~cm}$. Containers with sowed seeds were placed in the chamber with $400 \mathrm{ml}$ of water, which uniformly soaked to each pot. As a result, fixed moisture of soil of $80 \%$ was obtained for each sample. The temperature of the surrounding for the entire test was $18^{\circ} \mathrm{C}$. Infusions were prepared according to the methodology provided by Tyszyńska - Kownacka and Starek (1989). Two application methods of water extracts from wormwood (Artemisia absinthium) were used:

- sowable material was treated by soaking seeds for 24 hours in water extracts and then seeds were dried by air on the filter paper and sowed to the soil;

- non-dressed seeds were sowed to soil in the place of point application of $1 \mathrm{ml}$ of extract.

Non-dressed seeds sowed to soil without application of plant dressings constituted a control object. Experiment was set in four iterations for each combination, but averaged results were presented in the paper. Germinating plants were counted every day. From 1st to 15th day after sowing, systematically every 12 hours, occurring seedlings were counted and marked in order to determine abilities of germination and the course of plant germination. On this basis, the average time of plant germination expressed with Pieper index and the average time of obtaining uniformity of seedlings as well as the germination speed acc. 
to Maguire's coefficient were calculated. Detailed information concerning the biological part of this paper is presented in the publication by Czerwińska et al., (2016).

For a mathematical description of beetroot seedlings (Beta vulgaris L. var. Conditiva Alef.) of 'Czerowna Kula' variety, two types of the growth function were used: generalized logistic functions and Koya-Goshu functions. The following were assumed as a manifested form of logistic functions (Richards functions with time shift):

$$
N(t)=K \cdot[1+Q \cdot \exp (-B \cdot(t-C))]^{-v}
$$

Koya-Goshu function was assumed in the following form:

$$
N(t)=K \cdot\left[1+Q \cdot \exp \left(-B \cdot|t-C|^{A}\right)\right]^{-v}
$$

where $\mathrm{t}$ stands for time and $\mathrm{K}, \mathrm{Q}, \mathrm{B}, \mathrm{C}, \mathrm{A}, \mathrm{v}$ are function parameters (Koya and Goshu, 2013; Richards, 1959, Tatsuo Ito 1984). K parameter expressed an asymptotic value of the number of germinations for the time aiming at infinity, $\mathrm{Q}$ is a parameter related to the condition of the initial function $\mathrm{N}(\mathrm{t})$ (origin of the growth curve), parameter $\mathrm{B}$ [1/day] is the so-called growth rate, $\mathrm{C}$ [day] is a parameter which is responsible for time curve shift, $\mathrm{v}$ is a parameter responsible for relative location of the point of bending of the curve, $\mathrm{A}$ is a parameter introducing non-linearity of the time argument in the exponent.

For so defined functions, a computer model was developed (Figure 1) in Matlab 2016 program which enables determination of the value of parameters of the analysed functions, for which values of the square sum of differences between the predicted value from the model and experimental data, assume the minimal value.

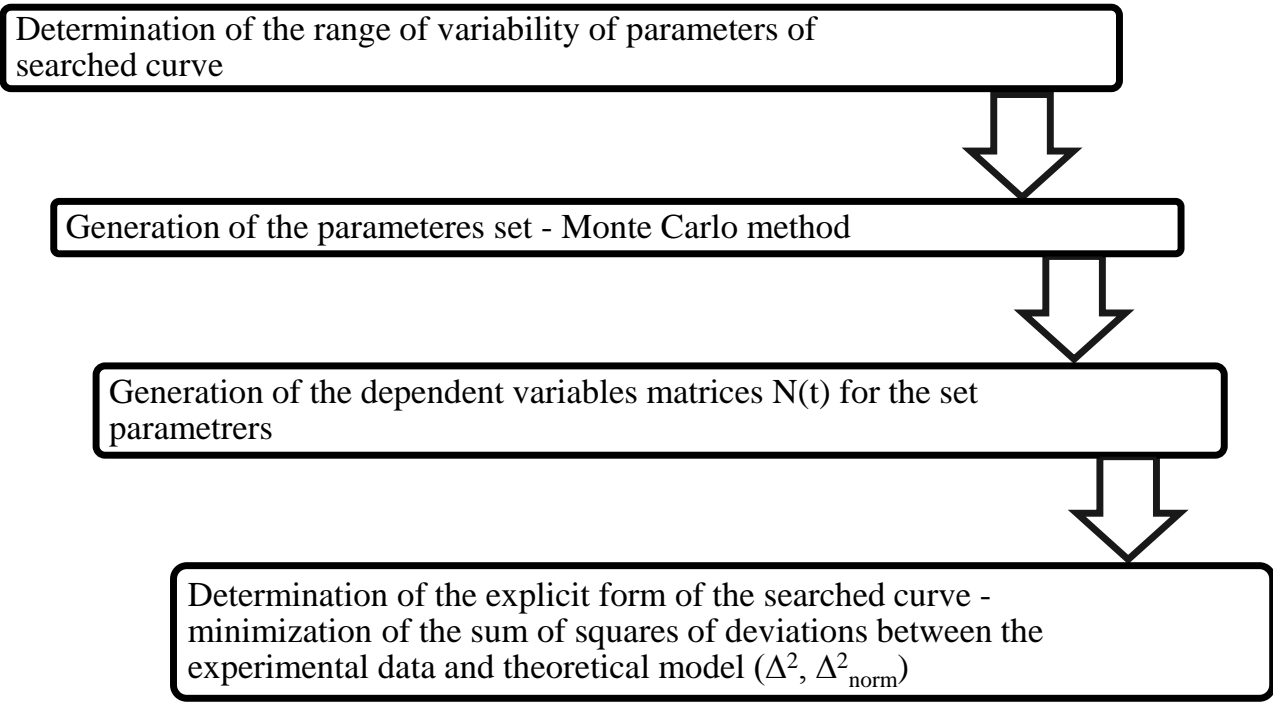

Figure 1. Schematic representation of computer model operation 
Modelling of beetroot seedlings...

In order to analyse the quality of adjustment of the obtained curves and for comparative purposes of two tested models, two rates were introduced: mean square error $\Delta 2$ and normalized value of the sum of squares of deviations $\Delta 2$ norm in the form:

$$
\begin{aligned}
& \Delta^{2}=\frac{1}{n} \sum_{i=1}^{15}\left(N_{i}^{\text {teor }}-N_{i}^{\exp }\right)^{2}, N_{i}^{\exp }=N^{\exp }\left(t_{i}\right) \\
& \Delta_{\text {norm }}^{2}=\frac{1}{N_{\max }} \sum_{i=1}^{15}\left(N_{i}^{\text {teor }}-N_{i}^{\exp }\right)^{2}, N_{\max }=\max _{i}\left(N_{i}^{\exp }\right)
\end{aligned}
$$

where $\mathrm{n}=31$ and stands for the number of measurement points (2nd readout /day for 15 days), Niexp and Niteor is a relevantly measured and calculated value of the germination percent within $\mathrm{i}$-time $(\mathrm{ti}=\{1,1,5,2, \ldots, 14,5,15\}$ days), and Nmax means the maximum value of the germination percent in the investigated period.

\section{Research results}

With the use of the developed computer model, the generalized logistic curves, defining time evolution of germination of beetroot seedlings for non-dressed seeds (controls), treated with extracts and after in-soil application of extracts, were determined (Figure 2)

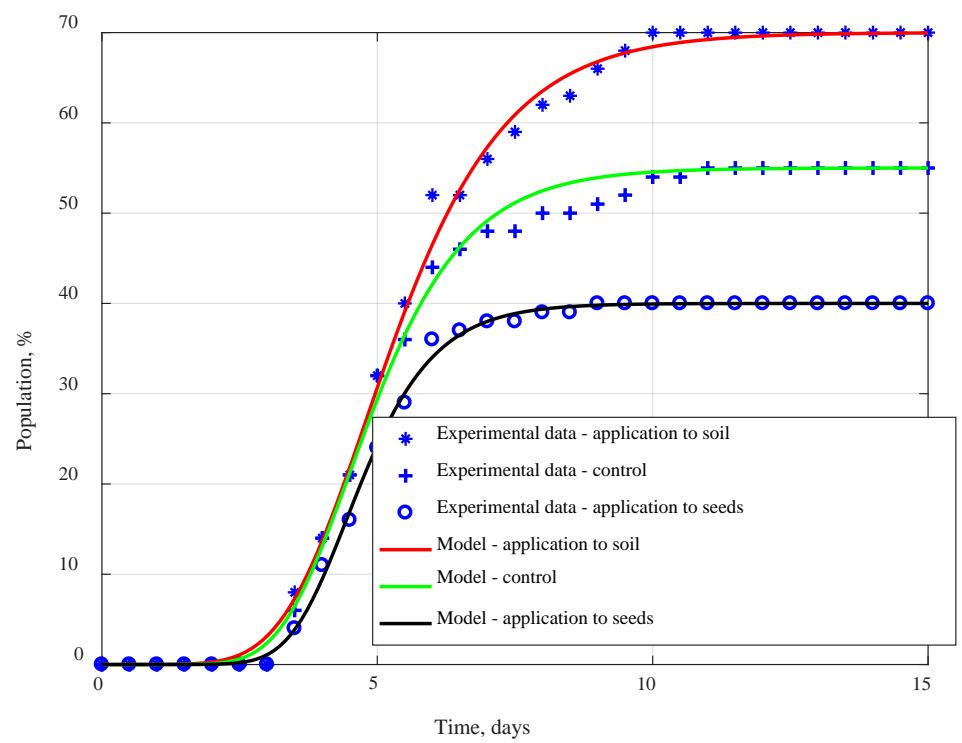

Figure 2. Time relations of germination of beetroot seedlings for non-treated seeds (control) and two methods of application of plant extracts (to soil and on seeds) - generalized logistic curves 
Agnieszka Szparaga, Ewa Czerwińska

Table 1. Includes the parameter value of the determined generalized logistic curves.

Table 1.

Parameters of the best adjusted generalized logistic function (Richards functions with time shift)

\begin{tabular}{lccccc}
\hline Parameters & $\mathrm{K}$ & $\mathrm{Q}$ & $\begin{array}{c}\mathrm{B}, \\
\text { 1/day }\end{array}$ & $\begin{array}{c}\mathrm{C}, \\
\text { day }\end{array}$ & $v$ \\
\hline Control & 55 & 1.01 & 0.87 & 1.91 & 9.42 \\
Application to soil & 70 & 3.31 & 0.72 & 0.13 & 8.94 \\
Application to seeds & 40 & 12.68 & 1.16 & 0.91 & 4.78 \\
\hline
\end{tabular}

It should be emphasised that there are many sets of function parameters for which similar values of adjustment to experimental results are obtained. The paper lists one of those sets, respectively for three investigated combinations which had the lowest value of the sum of squares of deviations - the global minimum. Each of the sets was selected from among approximately 20 million sets. For the analysed generalized logistic functions (Figure 2) time courses of the first and second derivative were determined (Figure 3a and b).
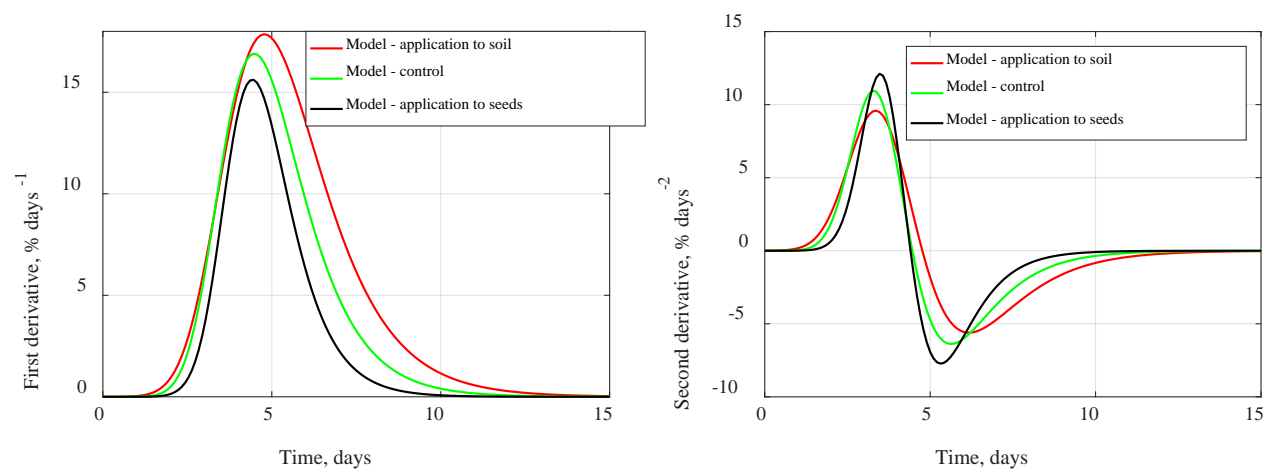

Figure 3. Time relation of a) first and b) second derivative of generalized logistic curves (fig. 2)

The highest rate germination growth is between 4th and 5th day, both for dressed and non-dressed seeds. Particularly detailed time values for which extremum of the derivative occurs are 4.40, 4.66 and 4.26 days respectively for non-dressed seeds (control) and application of extracts into soil and on seeds (Figure 3).Then, with the use of the developed computer model, for the same experimental data Koya-Goshu functions describing time evolution of beetroot seedlings germination for undressed seeds (control) and application of extracts to soil and on seeds were determined (Figure 4). 
Modelling of beetroot seedlings...

Table 2 includes the parameter value of the determined Koya-Goshu functions.

Table 2.

Parameters of the best adjusted Koya-Goshu functions

\begin{tabular}{lcccccc}
\hline Parameters & $\mathrm{K}$ & $\mathrm{Q}$ & $\begin{array}{c}\mathrm{B}, \\
\text { 1/day }\end{array}$ & $\begin{array}{c}\mathrm{C}, \\
\text { day }\end{array}$ & $v$ & $\mathrm{~A}$ \\
\hline Control & 55 & 17.54 & 2.99 & 1.44 & 9.86 & 0.5 \\
Application to soil & 70 & 17.38 & 2.83 & 1.50 & 9.18 & 0.5 \\
\multirow{2}{*}{ Application to seeds } & 40 & 19.92 & 3.23 & 1.70 & 8.86 & 0.5 \\
\hline
\end{tabular}

However, the obtained Koya-Goshu functions which prove the best adjustment to experimental results (Figure. 4) show lack of interpretation on the biological ground between 0 and 1st day of research (indicated in figure 4).

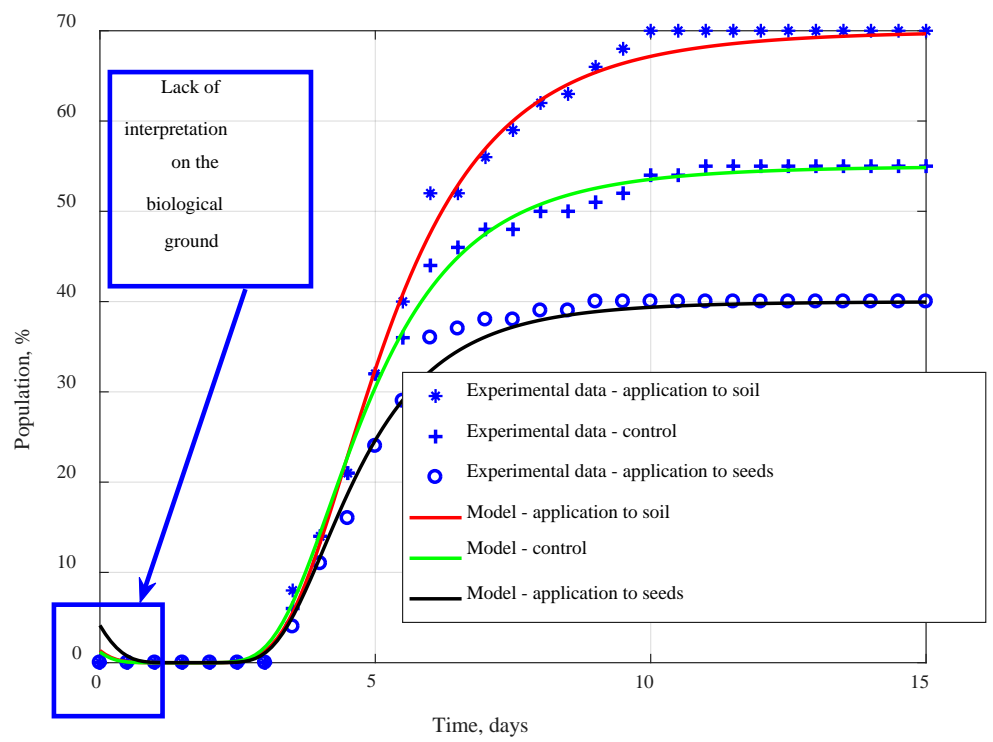

Figure 4. Time relations of germinations of beetroot seedlings for non-treated seeds (control) and two methods of application of plant extracts (to soil and on seeds) - Koya-Goshu functions

This problem was solved by means of the so-called Heaviside function $\mathrm{H}(\mathrm{t}-\mathrm{t} 0)$, which ensured correct interpretation of results i.e., amount of germinations may not decrease with time and of course it must grow from zero. For the analysed Koya-Goshu functions (Figure 4) also time courses of the first and second derivative were determined (Figure 5a and b) 
for which modification was introduced with Heavisdie function $\mathrm{H}(\mathrm{t}-\mathrm{t} 0)$ in order to obtain correct interpretation on the biological basis between the 0 and 1st day from sowing for all investigated combinations.

As in case of adjustment obtained with generalized logistic functions, the highest growth rate of germinations is between 4th and 5th day, both for dressed and undressed seeds. Particularly detailed time values, for which extremum of the derivative occurs are 4.11, 4,42 and 4.05 days respectively for non-dressed seeds (control) and application of obtained plant extracts into soil and on seeds (Figure $5 \mathrm{a}$ and $\mathrm{b}$ ).
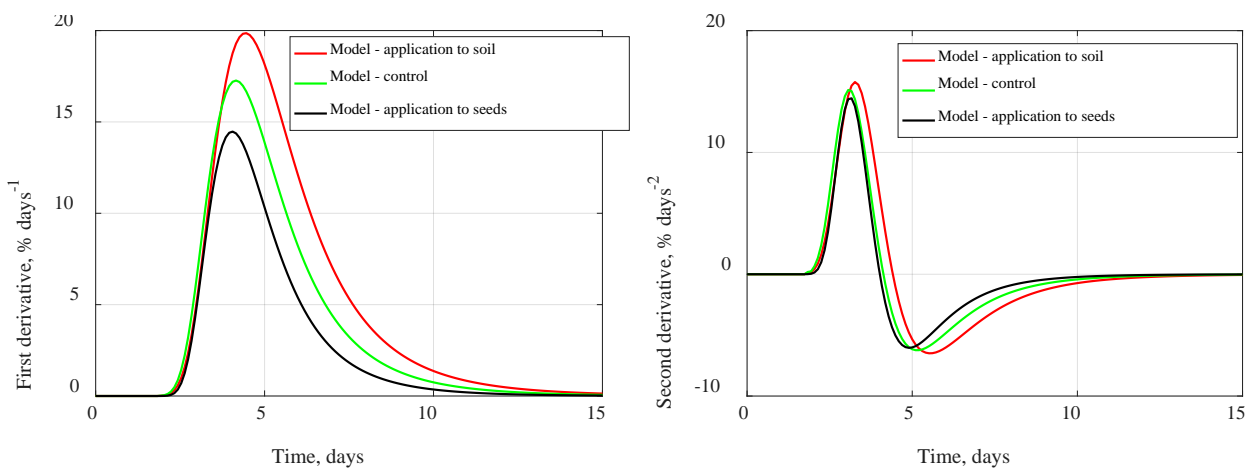

Figure 5. Time relation of a) first and b) second derivative of Koya-Goshu function (fig. 4)

In order to compare two tested models, table 1 presents results of adjusting generalized logistic curves and Koya-Goshu functions for non-dressed seeds (control) and dressed with extract to soil and on seeds.

Table 3.

List of results of adjustment of generalized logistic curves and Koya-goshu function for non-dressed seeds (control), dressed with extracts and after in-soil application of extracts

\begin{tabular}{lcccc}
\hline \multirow{2}{*}{ Parameters } & \multicolumn{3}{c}{ Koya-Goshu model } & \multicolumn{2}{c}{ Logistic generalized model } \\
\cline { 2 - 5 } & $\Delta^{2}$ & $\Delta_{\text {norm }}^{2}$ & $\Delta^{2}$ & $\Delta_{\text {norm }}^{2}$ \\
\hline Control & 31.14 & 0.56 & 61.22 & 1.11 \\
Application to soil & 62.79 & 0.89 & 64.42 & 0.92 \\
Application to seeds & 56.87 & 1.42 & 11.20 & 0.28 \\
\hline
\end{tabular}

Analysis of the results of adjustment presented in table 3 leads to a statement that for control, Koya-Goshu model has almost twofold better adjustment to experimental results in comparison to the generalized logistic model. However, in case of application on seeds, the generalized logistic model shows approximately fivefold better adjustment to experimental results. Certainly, one should remember that this result takes place at the assumption that Koya-Goshu model cannot be transformed to the generalized logistic model. 


\section{Conclusions}

Based on the collected experimental data and numerical research, it was stated that for control Koya-Goshu model has better adjustment (approximately two times lower value of $\Delta 2)$ to experimental results in comparison to the generalized logistic model. In case of application of plant extracts on seeds, the generalized logistic model (Richards model with time shift) shows better adjustment to experimental results i.e. approximately five times lower value of $\Delta 2$ in comparison to Koya-Goshu model, and does not require the introduced functions of the unit jump (Heaviside) in order to ensure correct interpretation of the obtained curves on the biological ground.

\section{References}

Adaszyńska, M., Swarcewicz, M., Markowska-Szczupak, A. (2013). Comparison of chemical composition and antimicrobial activity of lavender varieties from Poland. Postępy Fitoterapii, 2, 90-96.

Bošković, M., Baltić, Ž.M., Ivanović, J., Đurić, J., Lončina, J. Dokmanović, M., Marković, R. (2013). Use of essential oils in order to prevent foodborne illnesses caused by pathogens in meat. Tehnologija mesa, 54(1), 14-20.

Bozin, B., Mimica-Dukic, N., Simin, N., Anackov, G. (2006). Characterization of the volatile composition of essential oils of some Lamiaceae species and the antimicrobial and antioxidant activities of the entire oils. Journal of Agriculture and Food Chemistry, 54, 1822-1828.

Brachaczek, A., Kaczmarek, J., Kosiada, T., Jędryczka, M. (2012). Występowanie suchej zgnilizny kapustnych na wybranych odmianach rzepaku ozimego i ich plon w warunkach doświadczeń łanowych w Wielkopolsce Rośliny Oleiste, XXXIII, 56-72.

Bradford, K.J. (1990). A water relation analysis of seed germination rates. Plant Physiologicol, 94, 840-849.

Brown, R.F., Mayer, D.G. (1988). Representing cumulative germination. The use of the Weibull function and other empirically derived curves. Annals of Botany, 61, 127-138.

Burkhart H.E., Tomé M. (2012). Modeling forest trees and stands. Springer-Verlag. London. ISBN 9789400715974.

Carlson T. (1913). Über geschwindigkeit und grösse der hefevermehrung in Würze. Biochemische Zeitschrift, 57, 313-334.

Czerwińska, E. (2015). Właściwości przeciwbakteryjne i przeciwgrzybowe wybranych roślin zielonych i ich części. Acta Scientiarum Polonorum Technica Agraria, 14(1-2), 13-22.

Czerwińska, E., Szparaga, A., Deszcz E. (2015). Ocena wpływu zaprawiania wyciągami roślinnymi na zdolność kiełkowania nasion łubinu żółtego i grochu siewnego. Zeszyty Naukowe Uniwersytetu Przyrodniczego we Wroclawiu seria Rolnictwo, 612, 7-19.

Czerwińska, E., Szparaga, A. (2015a). Żywotność i zdrowotność nasion roślin oleistych traktowanych wyciągami roślinnymi. Acta Scientiarum Polonorum Technica Agraria, 14(1,2), 47-60.

Czerwińska, E., Szparaga, A., Deszcz, E. (2015b). Ocena wpływu zaprawiania wyciągami roślinnymi na zdolność kiełkowania nasion buraków. Zeszyty Naukowe Uniwersytetu Przyrodniczego we Wroclawiu, Rolnictwo, CXII, 7-20.

Czerwińska, E., Szparaga, A., Piskier, T., Deszcz, E. (2016). Effect of the application methods of natural plant extract on emergence of beets. Journal of Research and Applications in Agricultural Engineering, 61(3), 67-71.

Eberhardt, L.L. and Breiwick, J.M. (2012). Models for Population Growth Curves. ISRN Ecology, 2012, 1-5.

France, J., Thornley, J. H. M. (1984). Mathematical Models in Agriculture. Butterworths CAB International London. ISBN 0408108681. 
Hageseth, G.T., Joyner, R.D. (1975). Kinetics and thermodynamics of isothermal seed germination. Journal of. Theoretical Biology, 53, 51-65.

Hsu, F.H., Nelson, C.J., Chow, W.S. (1984). A mathematical model to utilize the logistic function in germination and seedling growth. Journal of Experimental Botany, 35, 1629-1640.

Ito, T., Osumi, S. (1984). An analysis of the basal area growth in even- aged pure stands based on the Richards growth function. Journal of the Japanese Society for Horticultural, 66(3), 99-108.

Koya, P.R., Goshu, A.T. (2013). Generalized Mathematical Model for Biological Growths. Open Journal of Modelling and Simulation, 1, 42-53.

Krebs, C.J. (1985). The Experimental Analysis of Distribution and Abundance. Harper and Row. New York. ISBN 0065004108.

Morgan, B.J.T. (1976). Stochastic models of groupings changes, Advances in Applied Probability, $8,30$.

Mrówczyński, M., Korbas, M., Praczyk, T., Gwiazdowski, R., Jajor, E., Pruszyński, G., Wachowiak, H. (2009). Ochrona roślin w integrowanej produkcji rzepaku. Rośliny Oleiste, XXX, 245-256.

Muszyński, S., Świetlicka, I., Świetlick,i M., Gładyszewska, B. (2015). Modelowanie kinetyki kiełkowania nasion pomidora z wykorzystaniem równania Gompertza. Acta Scientiarum Polonorum Technica Agraria, 14(1-2), 61-69.

O’Neill, M.E., Thomson, P.C., Jacobs, B.C., Brain, P., Butler, R.C., Turner, H., Mitakda, B. (2004). Fitting and comparing seed germination models with a focus on the inverse normal distribution Austral. Journal Statistics, 46, 349-366.

Odabas, M.S., Mut, Z. (2007). Modeling the effect of temperature on percentage and duration of seed germination grain legumes and cereals. American Journal of Physiology, 2, 303-310.

Orzeszko-Rywka, A. , Rochalska, M. (2007). Preliminary assessment of efficiency of some ecological methods of sugar beet seed dressing. Journal of Research and Applications in Agricultural Engineering, 52(4), 10-13.

Richards, F.J. (1959). A flexible growth function for empirical use. Journal of Experimental Botany, 10, 290-300

Rochalska, M., i Orzeszko-Rywka, A. (2009). Zastosowanie naturalnych substancji roślinnych jako zapraw nasiennych dla upraw ekologicznych. Journal of Research and Applications in Agricultural Engineering, 54(4), 74-80.

Rochalska, M. , Orzeszko-Rywka, A., Tracz, M. (2010). Estimation efficiency of powdered herbs of crop seeds treatment. Journal of Research and Applications in Agricultural Engineering, 55(4), 67-72.

Shafii, B., Price, W.J. (2001). Estimation of cardinal temperatures in germination data analysis. Journal of Agricultural, Biological and Environmental Statistics, 6, 356-366.

Shafii, B., Price, W.J., Swensen, J.B., Murray, G.A. (1991). Nonlinear estimation of growth curve models for germination data analysis. The Third Conference On Applied Statistics In Agriculture. Kansas State University. Manhattan. KS, 19-42.

Tsoularis, A., Wallace, J. (2002). Analysis of logistic growth models. Mathematical Biosciences, 179, 21-55.

Tyszyńska-Kownacka, D., Starek, T. (1989). Zioła w polskim domu. Wydawnictwo Warta. Warszawa. ISBN 8322502303 


\section{MODELOWANIE WSCHODÓW BURAKA ĆWIKLOWEGO Z WYKORZYSTANIEM ZMODYFIKOWANYCH UOGÓLNIONYCH FUNKCJI LOGISTYCZNYCH}

Streszczenie. Do opisu matematycznego wschodów wykorzystano zmodyfikowane uogólnione funkcje logistyczne (znane również jako funkcje Koya-Goshu). Funkcje te stanowią naturalną modyfikację klasycznie stosowanych funkcji Richardsa w opisie wzrostu roślin, wprowadzającą nieliniowy przyrost czasu w wykładniku exponenty oraz człon związany z przesunięciem czasowym. Dopasowanie krzywych do danych eksperymentalnych przeprowadzono w oparciu o minimalizacje sumy kwadratów różnic pomiędzy danymi eksperymentalnymi, a modelem matematycznym (metoda najmniejszych kwadratów). Rezultaty badań symulacyjnych pokazują, iż wyznaczone parametry krzywych (np. wartości parametru wzrostu, przesunięcia czasowego czy górnej granicy populacji) opisujących ilość wschodów w funkcji czasu pozostają w dobrej zgodności z interpretacją na gruncie biologicznym badanych procesów. Na podstawie przeprowadzonych badań stwierdzono, iż dla kontroli oraz aplikacji do gleby wyciągów roślinnych model Koya-Goshu posiada lepsze dopasowanie do wyników eksperymentalnych w stosunku do uogólnionego modelu logistycznego.

Słowa kluczowe: burak ćwikłowy, wschody, wyciągi wodne, funkcje logistyczne, funkcje KoyaGoshu 